Article

\title{
Evaluation of the Chemical and Antioxidant Properties of Wild and Cultivated Mushrooms of Ghana
}

\author{
Mary Obodai ${ }^{1}$, Isabel C.F.R. Ferreira ${ }^{2, *}$, Ângela Fernandes ${ }^{2}$, Lillian Barros ${ }^{2, *}$, \\ Deborah L. Narh Mensah ${ }^{1}$, Matilda Dzomeku ${ }^{1}$, Arailde F. Urben ${ }^{3}$, Juanita Prempeh ${ }^{1}$ and \\ Richard K. Takli ${ }^{1}$
}

1 CSIR-Food Research Institute, P.O. Box M20, Accra, Ghana; E-Mails: obodaime@yahoo.com (M.O.); lnarh@yahoo.com (D.L.N.M.); matildadela@yahoo.com (M.D.); Juanita_luv06@yahoo.com (J.P.); rtakli@yahoo.com (R.K.T.)

2 Mountain Research Centre (CIMO), ESA, Polytechnic Institute of Bragança, Campus de Santa Apolónia, apartado 1172, Bragança 5301-855, Portugal; E-Mail: afeitor@ipb.pt

3 Embrapa Recursos Genéticos e Biotecnologia-PqEB-Parque Estação Biológica, Final Av. W5 Norte, Caixa Postal 02372, CEP:70770-900 Brasília, DF, Brazil; E-Mail:arailde.urben@embrapa.br

* Authors to whom correspondence should be addressed; E-Mails: iferreira@ipb.pt (I.C.F.R.F.); lillian@ipb.pt (L.B.); Tel.: +351-273-303-219 (I.C.F.R.F.); +351-273-303-200 (L.B.); Fax: +351-273-325-405 (I.C.F.R.F.); +351-273-325-405 (L.B.).

External Editor: Marcello Iriti

Received: 27 October 2014; in revised form: 12 November 2014 / Accepted: 21 November 2014 / Published: 26 November 2014

\begin{abstract}
Knowledge of the chemical composition of both wild and cultivated edible mushrooms in Ghana is limited. This study reports their nutritional value, composition in lipophilic and hydrophilic molecules, minerals and antioxidant properties. The samples were found to be nutritionally rich in carbohydrates, ranging from $64.14 \pm 0.93 \mathrm{~g}$ in Pleurotus ostreatus strain EM-1 to $80.17 \pm 0.34 \mathrm{~g}$ in Lentinus squarrosulus strain LSF. The highest level of proteins $(28.40 \pm 0.86 \mathrm{~g})$ was recorded in the mentioned P. ostreatus strain. Low fat contents were registered in the samples, with Auricularia auricula recording the lowest value. High levels of potassium were also observed with the following decreasing order of elements: $\mathrm{K}>\mathrm{P} \sim \mathrm{Na}>\mathrm{Mg}>\mathrm{Ca}$. High levels of antioxidants were also observed, thus making mushrooms suitable to be used as functional foods or nutraceutical sources. Furthermore, this study provides new information regarding chemical properties of mushrooms from Ghana, which is very important for the biodiversity characterization of this country.
\end{abstract}


Keywords: wild mushrooms; nutritional value; antioxidant potential; cultivated mushrooms; macro- and micro-elements

\section{Introduction}

Wild mushrooms are considered a popular delicacy in several countries all over the world and are collected and consumed when in season. In Ghana, these wild mushrooms are collected in early March to April and later on in September to October from the forests in the rural areas and subsequently sold at the urban centers. This is an old tradition and a well-established activity, which is gender-related and generally regarded as work for women and children [1].

Wild mushrooms are rich in minerals and have high levels of water, proteins, fibers and carbohydrates [2]. The two most commonly preferred wild edible mushroom species collected in Ghana are Termitomyces and Volvariella spp. These mushrooms are preferred for different reasons such as taste, attractiveness, uses as substitutes for meat or fish, aroma and medicinal values [3]. The genus Termitomyces, which is the most preferred and cherished in the country and in many African and Asian countries such as Zambia, Tanzania, Burundi, Thailand and Taiwan, cannot be currently cultivated as its cultivation is difficult because of the very specific condition under which it grows in Nature. It grows naturally, in symbiotic association with termites known as "fungus growers" (Macrotermitinae), which grow about 30 species of this genus worldwide [4]. Nutritionally, Termitomyces sp. have been found to be higher in protein content than other edible mushrooms in Nigeria and Malawi $[5,6]$. The most common Termitomyces species recorded in Ghana are Termitomyces globulus, T. schimperi, T. robustus, $T$. reticulates, $T$. microcarpus and $T$. clypeatus, and these have a wide range of medicinal uses such as blood tonic, for malnourished children suffering from kwarshiokor (a protein deficiency condition), and also in the treatment of rheumatism and diarrhea [7].

Mushrooms have been reported as therapeutic foods useful in preventing diseases and they exhibit varied biological properties such as antibacterial, antimutagenic, antitumoral and antiviral activities [8,9]. These functional characteristics are mainly due to their chemical composition [10]. Traditionally, in Ghana rural people consume mushrooms also for medicinal reasons such as reducing obesity and lowering blood pressure in hypertensive patients, among others. Pleurotus tuber-regium has been used by traditional herbal doctors for increasing the weight of underweight children, treating asthma and high blood pressure, among others [11].

Since 1990, cultivation of mushrooms in Ghana, has mainly been for oyster mushrooms such as Pleurotus ostreatus, P. sajor-caju, and woodear mushrooms (Auricularia spp.) and quite recently, on an experimental basis, Lentinus squarrosulus. These have been cultivated on composted sawdust of Triplochiton scleroxylon and or mixtures with Chlorophora excelsa.

Little knowledge about these cultivated mushrooms in terms of chemical composition and antioxidant properties is available. Therefore, in the present study five cultivated and two wild mushroom samples were evaluated for their nutritional value, composition in lipophilic (saturated and unsaturated fatty acids) and hydrophilic (free sugars, organic acids and phenolic compounds) molecules, minerals (macro- 
and micro-elements), and antioxidant properties (free radical scavenging activity, reducing power and lipid peroxidation inhibition) to ascertain their values for the nutraceutical and food industries.

\section{Results and Discussion}

\subsection{Nutritional Value}

The nutritional value and energetic contribution of the studied edible mushrooms are shown in Table 1. Almost all species gave similar ash contents, except $A$. auricula, and the result for this species is in agreement with the literature [12], and it gave the lowest content in fat, but the highest energetic contribution, due to the highest protein levels. The total fat, protein and ash values obtained for P. tuber-regium in this work, is also in agreement with the values reported by Gbolagade et al. [13]. Nevertheless, the total fat found in P. sajor-caju and P. ostreatus is lower than the values reported for samples cultivated on banana and rice straw, respectively, 5.26 and $4.99 \mathrm{~g} / 100 \mathrm{~g}$ for P. sajor-caju, and 5.97 and $6.32 \mathrm{~g} / 100 \mathrm{~g}$ for P. ostreatus [14].

Concerning protein content, $P$. ostreatus gave the highest value. The values available in the literature are variable: 19.93 to $34.73 \mathrm{~g} / 100 \mathrm{~g}$ for samples cultivated on wheat straw supplemented with sugar beet [15]; $21 \mathrm{~g} / 100 \mathrm{~g}$ in $P$. ostreatus cultivated on wheat straw [16] and $9.62 \mathrm{~g} / 100 \mathrm{~g}$ in a sample cultivated on coffee husks [17]; the results obtained in this work are similar to those reported for a wild sample from Croatia [18].

The fatty acids composition, total saturated fatty acids (SFA), monounsaturated fatty acids (MUFA) and polyunsaturated fatty acids (PUFA) results are shown in Table 1. Twenty-four fatty acids were quantified in L. squarrosulus strain LSF and P. ostreatus, and twenty-three in P. tuber-regium, $T$. robustus, L. squarrosulus strain SQW, P. sajor-caju and A. auricula. A prevalence of PUFA over SFA was observed, except for $P$. tuber-regium, where SFA were dominant. The most abundant fatty acid in all the samples was linoleic acid (C18:2n6). The second most abundant fatty acid in P. tuber-regium, $P$. ostreatus,P. sajor-caju and A. auricula was oleic acid (C18:1n9), while in T. robustus, L. squarrosulus strain SQW and L. squarrosulus strain LSF it was palmitic acid (C16:0). The global percentages obtained for SFA, MUFA and PUFA in P. ostreatus and P. sajor-caju are very similar to those presented in other studies $[19,20]$.

\subsection{Lipophilic and Hydrophilic Compounds}

The results obtained for hydrophilic compounds (free sugars, organic acids and phenolic acids) are presented in Table 2. Trehalose was the most abundant sugar in all the samples; the highest level was found in L. squarrosulus strain LSF and P. ostreatus, while sucrose was only detected in A. auricula and fructose in L. squarrosulus strain LSF, P. ostreatus strain EM1 and P. sajor-caju strain PScW. 
Table 1. Nutritional value and lipophilic compounds of wild and cultivated mushrooms of Ghana (mean \pm SD).

\begin{tabular}{|c|c|c|c|c|c|c|c|}
\hline & $\begin{array}{c}\text { Pleurotus } \\
\text { tuber-regium }\end{array}$ & $\begin{array}{c}\text { Termitomyces } \\
\text { robustus }\end{array}$ & $\begin{array}{c}\text { Lentinus } \\
\text { squarrosulus } \\
\text { strain SQW }\end{array}$ & $\begin{array}{c}\text { Lentinus } \\
\text { squarrosulus } \\
\text { strain LSF }\end{array}$ & $\begin{array}{c}\text { Pleurotus } \\
\text { ostreatus strain } \\
\text { EM-1 }\end{array}$ & $\begin{array}{c}\text { Pleurotus } \\
\text { sajor-caju strain } \\
\text { PScW }\end{array}$ & $\begin{array}{c}\text { Auricularia } \\
\text { auricula }\end{array}$ \\
\hline \multicolumn{8}{|l|}{ Nutritional value } \\
\hline Fat $(g / 100 g)$ & $1.30 \pm 0.03^{\mathrm{e}}$ & $1.42 \pm 0.01 \mathrm{de}$ & $1.98 \pm 0.18^{b}$ & $1.72 \pm 0.05^{\mathrm{c}}$ & $1.49 \pm 0.01^{\mathrm{d}}$ & $2.93 \pm 0.07^{\mathrm{a}}$ & $0.82 \pm 0.03^{\mathrm{f}}$ \\
\hline Protein $(g / 100 \mathrm{~g})$ & $13.31 \pm 0.10^{\mathrm{d}}$ & $14.78 \pm 0.07^{\mathrm{c}}$ & $19.43 \pm 0.76^{b}$ & $12.51 \pm 0.36^{\mathrm{d}}$ & $28.40 \pm 0.86^{\mathrm{a}}$ & $15.33 \pm 0.45^{\mathrm{c}}$ & $19.27 \pm 0.80^{b}$ \\
\hline $\operatorname{Ash}(g / 100 \mathrm{~g})$ & $6.29 \pm 0.18^{\mathrm{a}}$ & $6.21 \pm 0.45^{\mathrm{a}}$ & $6.13 \pm 0.24^{\mathrm{ab}}$ & $5.60 \pm 0.11^{b}$ & $5.96 \pm 0.37^{\mathrm{ab}}$ & $6.38 \pm 0.09^{\mathrm{a}}$ & $3.05 \pm 0.43^{c}$ \\
\hline Carbohydrates (g/100 g) & $79.10 \pm 0.22^{\mathrm{bc}}$ & $77.60 \pm 0.34^{\mathrm{c}}$ & $72.45 \pm 0.88^{d}$ & $80.17 \pm 0.34^{\mathrm{b}}$ & $64.14 \pm 0.93^{\mathrm{e}}$ & $75.36 \pm 0.38^{d}$ & $76.86 \pm 0.63^{a}$ \\
\hline Energetic value (Kcal/100 g) & $381.34 \pm 0.41^{\mathrm{f}}$ & $382.26 \pm 1.311^{\mathrm{ef}}$ & $385.39 \pm 0.02^{\mathrm{cd}}$ & $386.16 \pm 0.50^{c}$ & $383.64 \pm 1.08^{\mathrm{de}}$ & $389.15 \pm 0.02^{b}$ & $391.88 \pm 1.11^{\mathrm{a}}$ \\
\hline \multicolumn{8}{|l|}{ Lipophilic compounds } \\
\hline C6:0 & $0.11 \pm 0.03$ & $0.22 \pm 0.05$ & $0.12 \pm 0.01$ & $0.06 \pm 0.00$ & $0.06 \pm 0.02$ & $0.05 \pm 0.01$ & $0.07 \pm 0.01$ \\
\hline C8:0 & $0.10 \pm 0.02$ & $0.07 \pm 0.00$ & $0.06 \pm 0.02$ & $0.06 \pm 0.00$ & $0.04 \pm 0.00$ & $0.03 \pm 0.01$ & $0.07 \pm 0.02$ \\
\hline $\mathrm{C} 10: 0$ & $0.11 \pm 0.02$ & $0.06 \pm 0.01$ & $0.08 \pm 0.01$ & $0.04 \pm 0.00$ & $0.05 \pm 0.01$ & $0.04 \pm 0.01$ & $0.05 \pm 0.01$ \\
\hline $\mathrm{C} 12: 0$ & $0.29 \pm 0.05$ & $0.11 \pm 0.00$ & $0.15 \pm 0.01$ & $0.09 \pm 0.02$ & $0.07 \pm 0.00$ & $0.09 \pm 0.01$ & $0.11 \pm 0.02$ \\
\hline $\mathrm{C} 14: 0$ & $1.12 \pm 0.07$ & $0.91 \pm 0.03$ & $0.67 \pm 0.04$ & $0.53 \pm 0.07$ & $0.44 \pm 0.04$ & $0.57 \pm 0.06$ & $0.59 \pm 0.05$ \\
\hline C14:1 & $0.09 \pm 0.04$ & $0.04 \pm 0.00$ & $0.03 \pm 0.01$ & $0.03 \pm 0.00$ & $0.03 \pm 0.00$ & $0.04 \pm 0.01$ & $0.04 \pm 0.01$ \\
\hline $\mathrm{C} 15: 0$ & $1.79 \pm 0.04$ & $1.79 \pm 0.05$ & $1.20 \pm 0.02$ & $1.51 \pm 0.16$ & $0.94 \pm 0.02$ & $1.29 \pm 0.09$ & $2.02 \pm 0.11$ \\
\hline C15:1 & $0.06 \pm 0.01$ & $0.03 \pm 0.01$ & $0.14 \pm 0.05$ & $0.08 \pm 0.00$ & $0.05 \pm 0.01$ & $0.04 \pm 0.01$ & $0.03 \pm 0.00$ \\
\hline C16:0 & $21.19 \pm 0.46$ & $20.87 \pm 0.30$ & $19.62 \pm 0.23$ & $18.04 \pm 1.41$ & $14.31 \pm 0.06$ & $17.84 \pm 0.87$ & $18.75 \pm 1.27$ \\
\hline C16:1 & $0.61 \pm 0.03$ & $0.35 \pm 0.00$ & $0.38 \pm 0.03$ & $0.33 \pm 0.05$ & $0.24 \pm 0.04$ & $1.13 \pm 0.13$ & $0.25 \pm 0.02$ \\
\hline $\mathrm{C} 17: 0$ & $1.46 \pm 0.06$ & $0.85 \pm 0.00$ & $0.97 \pm 0.06$ & $1.05 \pm 0.03$ & $0.36 \pm 0.01$ & $0.40 \pm 0.03$ & $0.41 \pm 0.05$ \\
\hline C18:0 & $9.58 \pm 0.89$ & $3.98 \pm 0.10$ & $3.52 \pm 0.15$ & $3.07 \pm 0.06$ & $4.36 \pm 0.19$ & $4.59 \pm 0.08$ & $11.26 \pm 0.13$ \\
\hline C18:1n9 & $21.21 \pm 0.12$ & $9.52 \pm 0.29$ & $7.89 \pm 0.22$ & $8.67 \pm 0.30$ & $18.30 \pm 0.33$ & $22.62 \pm 0.31$ & $27.20 \pm 0.15$ \\
\hline C18:2n6 & $32.28 \pm 0.60$ & $59.19 \pm 0.17$ & $62.41 \pm 0.66$ & $63.34 \pm 1.43$ & $58.46 \pm 0.73$ & $48.57 \pm 1.46$ & $34.61 \pm 0.99$ \\
\hline $\mathrm{C} 18: 3 \mathrm{n} 3$ & $1.08 \pm 0.19$ & $0.20 \pm 0.03$ & $1.16 \pm 0.11$ & $1.03 \pm 0.03$ & $0.20 \pm 0.03$ & $0.24 \pm 0.04$ & $1.63 \pm 0.03$ \\
\hline
\end{tabular}


Table 1. Cont.

\begin{tabular}{|c|c|c|c|c|c|c|c|}
\hline & $\begin{array}{c}\text { Pleurotus } \\
\text { tuber-regium }\end{array}$ & $\begin{array}{c}\text { Termitomyces } \\
\text { robustus }\end{array}$ & $\begin{array}{c}\text { Lentinus } \\
\text { squarrosulus } \\
\text { strain SQW }\end{array}$ & $\begin{array}{c}\text { Lentinus } \\
\text { squarrosulus } \\
\text { strain LSF }\end{array}$ & $\begin{array}{c}\text { Pleurotus } \\
\text { ostreatus strain } \\
\text { EM-1 }\end{array}$ & $\begin{array}{c}\text { Pleurotus } \\
\text { sajor-caju strain } \\
\text { PScW } \\
\end{array}$ & $\begin{array}{c}\text { Auricularia } \\
\text { auricula }\end{array}$ \\
\hline \multicolumn{8}{|l|}{ Lipophilic compounds } \\
\hline C20:0 & $0.53 \pm 0.05$ & $0.12 \pm 0.01$ & $0.12 \pm 0.01$ & $0.09 \pm 0.01$ & $0.15 \pm 0.01$ & $0.18 \pm 0.00$ & $0.35 \pm 0.04$ \\
\hline C20:1 & $0.20 \pm 0.02$ & $0.09 \pm 0.00$ & $0.08 \pm 0.02$ & $0.08 \pm 0.00$ & $0.10 \pm 0.02$ & $0.08 \pm 0.01$ & $0.06 \pm 0.01$ \\
\hline $\mathrm{C} 20: 2$ & $0.18 \pm 0.00$ & $0.14 \pm 0.00$ & $0.15 \pm 0.01$ & $0.16 \pm 0.02$ & $0.19 \pm 0.03$ & $0.19 \pm 0.02$ & $0.13 \pm 0.02$ \\
\hline $\mathrm{C} 20: 3 \mathrm{n} 3+\mathrm{C} 21: 0$ & $0.21 \pm 0.03$ & $0.08 \pm 0.01$ & $0.10 \pm 0.01$ & $0.15 \pm 0.01$ & $0.18 \pm 0.01$ & $0.17 \pm 0.01$ & $0.08 \pm 0.01$ \\
\hline $\mathrm{C} 20: 5 \mathrm{n} 3$ & nd & nd & nd & $0.19 \pm 0.03$ & $0.18 \pm 0.02$ & nd & nd \\
\hline $\mathrm{C} 22: 0$ & $1.16 \pm 0.17$ & $0.10 \pm 0.01$ & $0.25 \pm 0.03$ & $0.38 \pm 0.09$ & $0.33 \pm 0.02$ & $0.40 \pm 0.07$ & $0.75 \pm 0.09$ \\
\hline $\mathrm{C} 22: \ln 9$ & $1.90 \pm 0.11$ & $0.26 \pm 0.00$ & $0.23 \pm 0.04$ & $0.16 \pm 0.08$ & $0.20 \pm 0.02$ & $0.30 \pm 0.02$ & $0.16 \pm 0.04$ \\
\hline $\mathrm{C} 23: 0$ & $1.72 \pm 0.24$ & $0.09 \pm 0.00$ & $0.09 \pm 0.02$ & $0.18 \pm 0.05$ & $0.08 \pm 0.00$ & $0.10 \pm 0.00$ & $0.07 \pm 0.02$ \\
\hline $\mathrm{C} 24: 0$ & $3.03 \pm 0.02$ & $0.94 \pm 0.09$ & $0.59 \pm 0.06$ & $0.68 \pm 0.02$ & $0.69 \pm 0.02$ & $1.04 \pm 0.02$ & $1.33 \pm 0.15$ \\
\hline Total SFA ( $\%$ of total FA) & $42.19 \pm 0.16^{\mathrm{a}}$ & $30.10 \pm 0.05^{\mathrm{c}}$ & $27.43 \pm 0.05^{\mathrm{cd}}$ & $25.78 \pm 0.15^{\mathrm{d}}$ & $21.87 \pm 0.03^{\mathrm{e}}$ & $26.62 \pm 0.09^{d}$ & $35.82 \pm 0.15^{b}$ \\
\hline Total MUFA ( $\%$ of total FA) & $24.07 \pm 0.07^{\mathrm{b}}$ & $10.28 \pm 0.06^{\mathrm{d}}$ & $8.75 \pm 0.06^{\mathrm{d}}$ & $9.36 \pm 0.07^{\mathrm{d}}$ & $18.92 \pm 0.07^{\mathrm{c}}$ & $24.21 \pm 0.08^{b}$ & $27.74 \pm 0.20^{\mathrm{a}}$ \\
\hline Total PUFA ( $\%$ of total FA) & $33.75 \pm 0.20^{d}$ & $59.62 \pm 0.06^{b}$ & $63.82 \pm 0.26^{\mathrm{ab}}$ & $64.87 \pm 0.30^{\mathrm{a}}$ & $59.21 \pm 0.16^{b}$ & $49.17 \pm 0.38^{\mathrm{c}}$ & $36.44 \pm 0.26^{\mathrm{d}}$ \\
\hline
\end{tabular}

Nd-not detected. Caproic acid (C6:0); Caprylic acid (C8:0); Capric acid (C10:0); Lauric acid (C12:0); Myristic acid (C14:0); Myristoleic acid (C14:1); Pentadecanoic acid (C15:0); cis-10-Pentadecenoic acid (C15:1); Palmitic acid (C16:0); Palmitoleic acid (C16:1); Heptadecanoic acid (C17:0); Stearic acid (C18:0); Oleic acid (C18:1n9); 12- Linoleic acid (C18:2n6); $\alpha$-Linolenic acid (C18:3n3); Arachidic acid (C20:0); Eicosenoic acid (C20:1); cis-11,14-Eicosadienoic acid (C20:2); cis-11,14,17-Eicosatrienoic acid and Heneicosanoic acid (C20:3n3 + C21:0); cis-5,8,11,14,17-Eicosapentaenoic acid (C20:5n3); Behenic acid (C22:0); Erucic acid (C22:1n9); Tricosanoic acid (C23:0); Lignoceric acid (C24:0). In each row, different letters mean significant differences between species $(p<0.05)$. 
Table 2. Composition in hydrophilic compounds of wild and cultivated mushrooms of Ghana (mean \pm SD).

\begin{tabular}{|c|c|c|c|c|c|c|c|}
\hline & $\begin{array}{c}\text { Pleurotus tuber- } \\
\text { regium }\end{array}$ & $\begin{array}{c}\text { Termitomyces } \\
\text { robustus }\end{array}$ & $\begin{array}{c}\text { Lentinus } \\
\text { squarrosulus } \\
\text { strain SQW } \\
\end{array}$ & $\begin{array}{c}\text { Lentinus } \\
\text { squarrosulus } \\
\text { strain LSF } \\
\end{array}$ & $\begin{array}{c}\text { Pleurotus } \\
\text { ostreatus strain } \\
\text { EM-1 } \\
\end{array}$ & $\begin{array}{c}\text { Pleurotus } \\
\text { sajor-caju strain } \\
\text { PScW } \\
\end{array}$ & $\begin{array}{c}\text { Auricularia } \\
\text { auricula }\end{array}$ \\
\hline \multicolumn{8}{|l|}{ Free sugars $(\mathrm{g} / 100 \mathrm{~g} \mathrm{dw})$} \\
\hline Fructose & nd & nd & nd & $0.55 \pm 0.15^{\mathrm{a}}$ & $0.30 \pm 0.09^{b}$ & $0.32 \pm 0.01^{b}$ & nd \\
\hline Mannitol & $0.35 \pm 0.00^{\mathrm{e}}$ & $4.71 \pm 0.16^{\mathrm{a}}$ & $0.70 \pm 0.03^{\mathrm{d}}$ & $1.43 \pm 0.22^{\mathrm{c}}$ & $0.87 \pm 0.02^{\mathrm{d}}$ & $1.99 \pm 0.07^{b}$ & $0.68 \pm 0.01^{\mathrm{d}}$ \\
\hline Sucrose & nd & nd & nd & nd & nd & nd & $0.67 \pm 0.02$ \\
\hline Trehalose & $1.50 \pm 0.03^{\mathrm{f}}$ & $9.92 \pm 0.34^{\mathrm{c}}$ & $11.09 \pm 0.20^{b}$ & $12.76 \pm 0.34^{\mathrm{a}}$ & $12.74 \pm 0.13^{\mathrm{a}}$ & $6.61 \pm 0.10^{d}$ & $2.52 \pm 0.01^{\mathrm{e}}$ \\
\hline Total sugars & $1.85 \pm 0.03^{\mathrm{a}}$ & $14.63 \pm 0.50^{a}$ & $11.79 \pm 0.22^{\mathrm{c}}$ & $14.74 \pm 0.71^{\mathrm{a}}$ & $13.91 \pm 0.05^{b}$ & $8.92 \pm 0.18^{d}$ & $3.87 \pm 0.03^{\mathrm{e}}$ \\
\hline \multicolumn{8}{|l|}{ Organic acids $(g / 100 \mathrm{~g} \mathrm{dw})$} \\
\hline Oxalic acid & $0.69 \pm 0.00^{\mathrm{a}}$ & $0.33 \pm 0.01^{\mathrm{b}}$ & $0.17 \pm 0.01^{\mathrm{e}}$ & $0.30 \pm 0.00^{c}$ & $0.29 \pm 0.01 \mathrm{~cd}$ & $0.32 \pm 0.00^{b}$ & $0.27 \pm 0.02^{d}$ \\
\hline Fumaric acid & $0.01 \pm 0.01^{\mathrm{d}}$ & $0.16 \pm 0.01^{\mathrm{a}}$ & $0.09 \pm 0.01^{\mathrm{c}}$ & $0.13 \pm 0.02^{b}$ & $0.18 \pm 0.02^{\mathrm{a}}$ & $0.18 \pm 0.00^{\mathrm{a}}$ & $0.01 \pm 0.01^{\mathrm{d}}$ \\
\hline Total organic acids & $0.70 \pm 0.01^{\mathrm{a}}$ & $0.49 \pm 0.00^{\mathrm{b}}$ & $0.26 \pm 0.01^{\mathrm{d}}$ & $0.43 \pm 0.02^{c}$ & $0.47 \pm 0.03^{b}$ & $0.50 \pm 0.00^{b}$ & $0.28 \pm 0.03^{\mathrm{d}}$ \\
\hline \multicolumn{8}{|c|}{ Phenolic acids and cinnamic acid (mg/100 g dw) } \\
\hline$p$-Hydroxybenzoic acid & $0.08 \pm 0.00^{\mathrm{g}}$ & $2.43 \pm 0.02^{b}$ & $4.46 \pm 0.04{ }^{a}$ & $1.40 \pm 0.03^{\mathrm{d}}$ & $1.56 \pm 0.01^{\mathrm{c}}$ & $0.43 \pm 0.03^{\mathrm{f}}$ & $1.09 \pm 0.02^{\mathrm{e}}$ \\
\hline$p$-Coumaric acid & nd & $0.24 \pm 0.01^{\mathrm{a}}$ & $0.21 \pm 0.01^{b}$ & nd & $0.21 \pm 0.01^{b}$ & nd & nd \\
\hline Total phenolic acids & $0.08 \pm 0.02 \mathrm{~g}$ & $2.67 \pm 0.03^{b}$ & $4.67 \pm 0.05^{\mathrm{a}}$ & $1.40 \pm 0.03^{\mathrm{d}}$ & $1.77 \pm 0.02^{\mathrm{c}}$ & $0.43 \pm 0.03^{\mathrm{f}}$ & $1.09 \pm 0.02 \mathrm{e}$ \\
\hline Cinnamic acid & nd & $8.06 \pm 0.01^{\mathrm{a}}$ & $0.57 \pm 0.01^{\mathrm{d}}$ & $0.79 \pm 0.01^{\mathrm{c}}$ & $1.82 \pm 0.01^{\mathrm{b}}$ & $0.13 \pm 0.01^{\mathrm{e}}$ & $0.10 \pm 0.01^{\mathrm{f}}$ \\
\hline
\end{tabular}

$\mathrm{Nd}-$ not detected. In each row, different letters mean significant differences between species $(p<0.05)$. 
Reis et al. [21] also described the presence of fructose, mannitol and trehalose in a commercial sample of $P$. ostreatus, but in much lower amount than the one found in this work. Gupta et al. [22] also found the same free sugars (fructose, mannitol and trehalose) in a sample of P. sajor-caju cultivated on wheat straw supplemented with raw and detoxified mahua cake. Beluhan and Ranogajec [18] reported the presence of mannitol, trehalose, mannose and glucose in a wild sample of $P$. ostreatus from Croatia.

Oxalic and fumaric acids were the organic acids found in the studied mushroom species, with the prevalence of oxalic acid in all the samples. The profile of organic acids described by Barros et al. [23] for a commercial sample of $P$. ostreatus was slightly different since the authors also detected malic and citric acids.

$p$-Hydroxybenzoic, $p$-coumaric and cinnamic acids were also found in the studied species; $p$-hydroxybenzoic acid was found in all the samples, while $p$-coumaric acid was only detected in T. robustus, L. squarrosulus strain SQW and P. ostreatus. Cinnamic acid was found in almost all samples, with the exception of $P$. tuber-regium. Nevertheless, Reis et al. [24] described the presence of protocatechuic acid, in addition to the three ones previously mentioned, in a commercial sample of $P$. ostreatus. The levels of $p$-hydroxybenzoic acid described in this study were similar to the ones herein reported.

\subsection{Minerals}

The variations and mean concentrations of ten macro- (sodium, potassium, calcium, phosphorus and magnesium) (Table 3) and micro- elements (iron, zinc, copper and manganese), and the heavy metal lead (Table 3) were examined in the wild and cultivated species of the mushrooms under study. The samples were shown to be rich in potassium. The trend in decreasing order of macro elements content for the studied mushrooms was $\mathrm{K}>\mathrm{P} \sim \mathrm{Na}>\mathrm{Mg}>\mathrm{Ca}$.

Living organisms require varying amounts of "heavy metals". Iron, cobalt, copper, manganese, molybdenum, and zinc are required by humans, but excessive levels can be damaging to the organism. Other heavy metals such as mercury, plutonium, and lead are toxic metals and their accumulation over time in the bodies of animals can cause serious illnesses.

Copper $(\mathrm{Cu})$ as stated is an essential metal, which serve as a constituent of some metalloenzymes, and is required in haemoglobin synthesis and catalysis of metabolic growth [25]. The average concentration of $\mathrm{Cu}$ in the studied samples was $0.05 \mathrm{mg} / \mathrm{kg}$, which was far below the safe limit of $40 \mathrm{mg} / \mathrm{kg}$ set by WHO [26]. Copper levels in mushrooms reported in literature are 4.71-51.0 mg/kg [27], $13.4-50.6 \mathrm{mg} / \mathrm{kg}$ [28], and $12-181 \mathrm{mg} / \mathrm{kg}$ [29]. These values recorded for wild mushrooms correspond to samples collected near industrial sites.

Iron $(\mathrm{Fe})$ is an essential metal involved in biochemical processes. The average Fe content recorded in the studied wild and cultivated mushrooms was $2.33 \mathrm{mg} / \mathrm{kg}$ and $0.44 \mathrm{mg} / \mathrm{kg}$, respectively, which are below the safe limit of $15 \mathrm{mg} / \mathrm{kg}$ set by WHO. Levels of Fe reported in literature were 146-835 mg/kg [29], $31.3-1190 \mathrm{mg} / \mathrm{kg}$ [30], and 180-407 $\mathrm{mg} / \mathrm{kg}$ [31].

Manganese (Mn) is an essential metal needed for biological systems such as metalloproteins [32]. The lowest and the highest level of Mn present in the studied mushrooms were $0.02 \pm 7.07 \times 10^{-5} \mathrm{mg} / \mathrm{kg}$ and $0.04 \pm 0.09 \times 10^{-1} \mathrm{mg} / \mathrm{kg}$, respectively, which are also below the toxicity limit of $400-1000 \mathrm{mg} / \mathrm{kg}$. 
Table 3. Composition in macro- and micro-elements of wild and cultivated mushrooms of Ghana (mean $\pm \mathrm{SD}$ ).

\begin{tabular}{|c|c|c|c|c|c|c|}
\hline \multirow[b]{2}{*}{ Source } & \multirow[b]{2}{*}{ Mushroom species } & \multicolumn{5}{|c|}{ Concentrations of Macro Elements (mg/kg dw) } \\
\hline & & $\mathrm{Na}$ & $\mathrm{K}$ & $\mathrm{P}$ & $\mathrm{Ca}$ & $\mathrm{Mg}$ \\
\hline \multirow{2}{*}{ Wild } & Pleurotus tuber-regium & $5.00 \pm 1.41 \times 10^{-4} \mathrm{~b}$ & $7.46 \pm 7.07 \times 10^{-3 \mathrm{f}}$ & $4.46 \pm 7.07 \times 10^{-4} \mathrm{c}$ & $0.34 \pm 0.01 \times 10^{-1 \mathrm{e}}$ & $0.90 \pm 0.01 \times 10^{-1 \mathrm{~g}}$ \\
\hline & Termitomyces robustus & $2.90 \pm 0.01^{\mathrm{d}}$ & $20.30 \pm 0.07^{\mathrm{a}}$ & $4.05 \pm 7.07 \times 10^{-4} \mathrm{e}$ & $0.40 \pm 1.40 \times 10^{-4 \mathrm{~d}}$ & $0.72 \pm 7.78 \times 10^{-4 \mathrm{f}}$ \\
\hline \multirow{7}{*}{ Cultivated } & Lentinus squarrosulus strain SQW & $5.00 \pm 7.07 \times 10^{-4 b}$ & $11.66 \pm 7.07 \times 10^{-3 \mathrm{~d}}$ & $5.37 \pm 0.01^{b}$ & $0.47 \pm 0.04 \times 10^{-1 \mathrm{c}}$ & $1.42 \pm 0.07 \times 10^{-1 \mathrm{~b}}$ \\
\hline & Lentinus squarrosulus strain LSF & $3.65 \pm 0.07^{\mathrm{c}}$ & $15.40 \pm 0.28^{\mathrm{c}}$ & $4.44 \pm 2.82 \times 10^{-4 \mathrm{~d}}$ & $1.57 \pm 0.06^{\mathrm{a}}$ & $1.48 \pm 0.08 \times 10^{-1 \mathrm{a}}$ \\
\hline & Pleurotus ostreatus strain EM-1 & $3.80 \pm 0.01^{\mathrm{c}}$ & $17.40 \pm 0.01^{b}$ & $2.11 \pm 7.07 \times 10^{-5 \mathrm{f}}$ & $0.39 \pm 0.02 \mathrm{de}$ & $1.21 \pm 0.04 \times 10^{-1 \mathrm{~d}}$ \\
\hline & P. sajor-caju strain PScW & $15.00 \pm 7.07 \times 10^{-5 a}$ & $15.00 \pm 0.01^{\mathrm{c}}$ & $11.34 \pm 2.80 \times 10^{-4 \mathrm{a}}$ & $0.20 \pm 0.00^{\mathrm{f}}$ & $1.32 \pm 0.01^{\mathrm{c}}$ \\
\hline & Auricularia auricula & $2.00 \pm 7.07 \times 10^{-5 \mathrm{e}}$ & $10.60 \pm 0.01^{\mathrm{e}}$ & $1.39 \pm 7.07 \times 10^{-4 \mathrm{~g}}$ & $0.55 \pm 0.08 \times 10^{-1 \mathrm{~b}}$ & $1.09 \pm 0.01^{\mathrm{e}}$ \\
\hline & & \multicolumn{4}{|c|}{$\begin{array}{l}\text { Concentrations of Micro Elements } \\
\qquad(\mathrm{mg} / \mathrm{kg} \mathrm{dw})\end{array}$} & $\begin{array}{c}\text { Concentrations of Heavy } \\
\text { Metal (mg/kg dw) } \\
\end{array}$ \\
\hline & & $\mathrm{Fe}$ & $\mathrm{Mn}$ & $\mathrm{Zn}$ & $\mathrm{Cu}$ & $\mathrm{Pb}$ \\
\hline \multirow{2}{*}{ Wild } & Pleurotus tuber-regium & $2.40 \pm 7.07 \times 10^{-4 a}$ & $0.06 \pm 7.07 \times 10^{-4 b}$ & $0.13 \pm 2.10 \times 10^{-3 \mathrm{c}}$ & $0.04 \pm 7.07 \times 10^{-4 \mathrm{c}}$ & $0.13 \pm 7.78 \times 10^{-4} \mathrm{e}$ \\
\hline & Termitomyces robustus & $2.24 \pm 0.02 \times 10^{-1 b}$ & $0.07 \pm 7.07 \times 10^{-4 \mathrm{a}}$ & $0.15 \pm 0.01^{\mathrm{c}}$ & $0.05 \pm 1.41 \times 10^{-4} \mathrm{c}$ & $0.61 \pm 0.03 \times 10^{-1} \mathrm{a}$ \\
\hline \multirow{5}{*}{ Cultivated } & Lentinus squarrosulus strain SQW & $0.61 \pm 0.01^{\mathrm{c}}$ & $0.02 \pm 0.04 \times 10^{-1 \mathrm{~d}}$ & $0.20 \pm 7.07 \times 10^{-3 b}$ & $0.02 \times 10^{-1} \pm 3.54 \times 10^{-4 \mathrm{~d}}$ & $0.07 \pm 0.04 \times 10^{-1 \mathrm{f}}$ \\
\hline & Lentinus squarrosulus strain LSF & $0.56 \pm 0.02^{d}$ & $0.04 \pm 0.09 \times 10^{-1} \mathrm{c}$ & $0.15 \pm 0.03^{\mathrm{c}}$ & $0.08 \pm 7.07 \times 10^{-3}$ a & $0.41 \pm 0.06 \times 10^{-1 \mathrm{c}}$ \\
\hline & Pleurotus ostreatus strain EM-1 & $0.40 \pm 0.03^{\mathrm{e}}$ & $0.03 \pm 0.05 \times 10^{-1 \mathrm{de}}$ & $0.33 \pm 2.80 \times 10^{-3 a}$ & $0.06 \pm 8.49 \times 10^{-3} \mathrm{~b}$ & $0.40 \pm 0.04 \times 10^{-1 \mathrm{~d}}$ \\
\hline & P. sajor-caju strain PScW & $0.60 \pm 0.01^{\mathrm{c}}$ & $0.02 \pm 7.07 \times 10^{-5 \mathrm{e}}$ & $0.07 \pm 1.41 \times 10^{-4 \mathrm{~d}}$ & $0.02 \times 10^{-1} \pm 7.07 \times 10^{-4 \mathrm{~d}}$ & $0.07 \pm 0.01 \mathrm{~g}$ \\
\hline & Auricularia auricula & $0.37 \pm 0.06 \times 10^{-1} \mathrm{e}$ & $0.04 \pm 0.01 \times 10^{-1 \mathrm{~cd}}$ & $0.12 \pm 0.01^{\mathrm{c}}$ & $0.07 \pm 7.07 \times 10^{-4} \mathrm{ab}$ & $0.60 \pm 0.01^{b}$ \\
\hline
\end{tabular}

$\mathrm{Na}$-sodium; $\mathrm{K}$ - potassium; $\mathrm{P}$ — phosphorus; $\mathrm{Ca}$ —calcium; $\mathrm{Mg}$ - magnesium; $\mathrm{Fe}$-iron; Mn—manganese; $\mathrm{Zn}-\mathrm{zinc}$; $\mathrm{Cu}-\mathrm{copper} ; \mathrm{Pb}-$ lead. In each column, different letters mean significant differences between species $(p<0.05)$. 
The literature has reported levels of $\mathrm{Mn}$ as $14.2-69.7 \mathrm{mg} / \mathrm{kg}$ [28], 12.9-93.3 $\mathrm{mg} / \mathrm{kg}$ [29], and 14.5-63.6 mg/kg [31]. According to Vonugopal and Lucky [33], lead ( $\mathrm{Pb})$ is toxic even at trace levels and the impairment related to lead toxicity in humans include abnormal size and haemoglobin content of the erythrocytes, hyperstimulation of erythropoisis and inhibition of haem synthesis. The maximum level of $\mathrm{Pb}$ present in the studied wild mushrooms was $0.60 \pm 0.00 \mathrm{mg} / \mathrm{kg}$, which is far below the $10.0 \mathrm{mg} / \mathrm{kg}$ limit set by the WHO [26]. Lead levels reported in literature are $0.75-7.77 \mathrm{mg} / \mathrm{kg}$ [27], $1.43-4.17 \mathrm{mg} / \mathrm{kg}$ [29], and $0.40-2.80 \mathrm{mg} / \mathrm{kg}$ [34].

Zinc $(\mathrm{Zn})$ is an essential metal and a component of a wide variety of different enzymes in which it is involved in catalytic, structural and regulatory roles. The minimum and maximum levels of $\mathrm{Zn}$ present in the studied wild and cultivated samples were below the permissible limit of $60 \mathrm{mg} / \mathrm{kg}$ of $\mathrm{Zn}$ in foods [26]. Zn levels reported in literature were $45.2-173.8 \mathrm{mg} / \mathrm{kg}$ [28], 33.5-89.5 mg/kg [29], and $29.3-158 \mathrm{mg} / \mathrm{kg}$ [31]. The trend in decreasing order of elements present in wild and cultivated samples was $\mathrm{Fe}>\mathrm{Pb}>\mathrm{Zn}>\mathrm{Mn}>\mathrm{Cu}$ and $\mathrm{Fe}>\mathrm{Pb}>\mathrm{Zn}>\mathrm{Cu}>\mathrm{Mn}$, respectively. All these values were statistically lower than the acceptable safe limits set by the WHO.

The lower values recorded in this study as compared to other studies can be attributed to various factors such as the analytical methods used and the substrate on which they were cultivated. Mushrooms are known to possess a very effective mechanism that enables them to readily take up some heavy metals from the ecosystem [35]. The accumulation of heavy metals in mushrooms seems to be affected by environmental and fungal related factors. Environmental factors such as organic matter content, $\mathrm{pH}$ and metal concentration in soil and fungal factors such as the species, morphological part of the fruit body, developmental stages, age of mycelium, intervals between fructifications and biochemical composition [36].

\subsection{Antioxidant Activity}

Five in vitro assays were used to evaluate the antioxidant properties of the samples: Folin-Ciocalteu assay, ferricyanide/Prussian blue, scavenging effects on DPPH radicals, inhibition of $\beta$-carotene bleaching and inhibition of lipid peroxidation in brain cell homogenates, as shown in Table 4 . The results obtained indicate that all the samples tested exhibit some antioxidant potential. Globally, A. auricula gave the highest reducing power (measured by ferricyanide/Prussian blue assay) and DPPH radical scavenging activity. Nevertheless, L. squarrosulus strain SQW showed the highest reducing power (measured by the Folin-Ciocalteu assay), $\beta$-carotene bleaching inhibition and lipid peroxidation activity in TBARS assay. A reducing power of $281.15 \mathrm{AAE} \mathrm{mg} / \mathrm{g}$ has been recorded for ethanolic extracts of wild L. squarrosulus using the phosphomolybdenum (PMo) assay [37]. It should be highlighted that P. ostreatus gave higher antioxidant activity than a commercial sample studied by Reis et al. [24].

Among the two L. squarrosulus strains studied, strain SQW had a significantly higher antioxidant activity than strain LSF according to both the Folin-Ciocalteu reagent assay and the TBARS assay. On the contrary, a significantly lower antioxidant activity was recorded for strain SQW than strain LSF according to the DPPH radical scavenging activity assay. 
Table 4. Antioxidant activity of wild and cultivated mushrooms of Ghana (mean $\pm \mathrm{SD}$ ).

\begin{tabular}{|c|c|c|c|c|c|c|c|c|}
\hline & & $\begin{array}{c}\text { Pleurotus } \\
\text { tuber-regium }\end{array}$ & $\begin{array}{l}\text { Termitomyces } \\
\text { robustus }\end{array}$ & $\begin{array}{c}\text { Lentinus } \\
\text { squarrosulus } \\
\text { strain SQW } \\
\end{array}$ & $\begin{array}{c}\text { Lentinus } \\
\text { squarrosulus } \\
\text { strain LSF } \\
\end{array}$ & $\begin{array}{c}\text { Pleurotus ostreatus } \\
\text { strain } \\
\text { EM-1 } \\
\end{array}$ & $\begin{array}{c}\text { Pleurotus sajor-caju } \\
\text { strain } \\
\text { PScW }\end{array}$ & $\begin{array}{c}\text { Auricularia } \\
\text { auricula }\end{array}$ \\
\hline \multirow{2}{*}{$\begin{array}{l}\text { Reducing } \\
\text { power }\end{array}$} & $\begin{array}{c}\text { Folin-Ciocalteu } \\
\text { (mg GAE/g extract) }\end{array}$ & $11.08 \pm 01^{\mathrm{e}}$ & $26.68 \pm 0.71 b c$ & $49.04 \pm 1.06^{\mathrm{a}}$ & $26.47 \pm 0.27 \mathrm{bc}$ & $17.66 \pm 0.69^{d}$ & $25.47 \pm 0.03^{c}$ & $28.12 \pm 0.75^{b}$ \\
\hline & $\begin{array}{c}\text { Ferricyanide/Prussian } \\
\text { blue }\left(\mathrm{EC}_{50} ; \mathrm{mg} / \mathrm{mL}\right)\end{array}$ & $2.06 \pm 0.03^{\mathrm{a}}$ & $1.24 \pm 0.01^{\mathrm{d}}$ & $1.14 \pm 0.01^{\mathrm{e}}$ & $1.15 \pm 0.01^{\mathrm{e}}$ & $1.64 \pm 0.03^{b}$ & $1.35 \pm 0.01^{\mathrm{c}}$ & $0.70 \pm 0.01^{\mathrm{f}}$ \\
\hline \multirow{2}{*}{$\begin{array}{c}\text { Radical } \\
\text { scavenging } \\
\text { activity }\end{array}$} & $\begin{array}{c}\text { DPPH radical } \\
\text { scavenging activity } \\
\left(\mathrm{EC}_{50} ; \mathrm{mg} / \mathrm{mL}\right)\end{array}$ & $17.39 \pm 0.23^{\mathrm{a}}$ & $4.78 \pm 0.05^{\mathrm{d}}$ & $5.33 \pm 0.27^{c}$ & $3.68 \pm 0.10^{\mathrm{e}}$ & $5.28 \pm 0.17^{c}$ & $9.52 \pm 0.15^{b}$ & $2.01 \pm 0.09^{\mathrm{f}}$ \\
\hline & $\begin{array}{c}\beta \text {-carotene/linoleate } \\
\left(\mathrm{EC}_{50} ; \mathrm{mg} / \mathrm{mL}\right)\end{array}$ & $3.79 \pm 0.46^{\mathrm{a}}$ & $1.76 \pm 0.17^{\mathrm{c}}$ & $0.97 \pm 0.05^{\mathrm{d}}$ & $0.80 \pm 0.08^{\mathrm{d}}$ & $1.59 \pm 0.07^{\mathrm{c}}$ & $2.48 \pm 0.29^{b}$ & $1.76 \pm 0.09^{c}$ \\
\hline $\begin{array}{l}\text { Lipid } \\
\text { peroxidation } \\
\text { inhibition }\end{array}$ & $\begin{array}{c}\text { TBARS } \\
\left(\mathrm{EC}_{50} ; \mathrm{mg} / \mathrm{mL}\right)\end{array}$ & $1.04 \pm 0.05^{b}$ & $0.43 \pm 0.04^{\mathrm{d}}$ & $0.18 \pm 0.01^{\mathrm{e}}$ & $1.00 \pm 0.05^{b}$ & $0.15 \pm 0.01^{\mathrm{e}}$ & $0.75 \pm 0.07^{\mathrm{c}}$ & $1.51 \pm 0.15^{\mathrm{a}}$ \\
\hline
\end{tabular}

Concerning the Folin-Ciocalteu assay. Higher values mean higher reducing power; for the other assays. The results are presented in $\mathrm{EC}_{50}$ values. That means, higher values correspond to lower reducing power or antioxidant potential. $\mathrm{EC}_{50}$ : Extract concentration corresponding to $50 \%$ of antioxidant activity or 0.5 of absorbance for the Ferricyanide/Prussian blue assay. In each row, different letters mean significant differences between species $(p<0.05)$. 
Pleurotus tuber-regium showed the lowest antioxidant activity based on all the assays used with the exception of the TBARS assay, which indicated that the species antioxidant activity was higher than that of $A$. auricula but comparable to that of $L$. squarrosulus strain LSF. These results indicate that the in vitro assays used in determining the antioxidant activity of a given sample could give a biased impression about the antioxidant potential of the sample, as different groups of compounds present in the extract possibly react differently to the various reactive oxygen species used in the assays.

Ferreira et al. [38] have demonstrated that antioxidant potential of caps of Portuguese Lactarius deliciosus (L.) Gray and Tricholoma portentosum (Fr.) Quél. are higher than that of the stipes. It will therefore be interesting to determine the portion of the fruiting body of the mushrooms studied herein with the highest nutritional composition and antioxidant potential. This information will be useful for mushroom consumers and cultivators, who will be able to make informed decisions about the part of the mushrooms they should consume/sell more and for industries, which would be interested in utilizing the antioxidants in mushrooms for various applications.

\section{Experimental Section}

\subsection{Mushroom Species}

The mushroom species used in this study are presented in Table 5. The wild samples were dried in a fabricated field dryer for $6 \mathrm{~h}$, whilst the cultivated samples were sun dried for 2 days. All the samples were further pulverized and stored in the freezer until transported to Mountain Research Centre (CIMO), ESA, Polytechnic Institute of Bragança, Portugal for chemical composition analysis (unless minerals analysis) and antioxidant activity evaluation.

Table 5. Information about the studied mushroom species.

\begin{tabular}{|c|c|c|c|}
\hline Mushroom Species & Common Name & Edibility & Habitat \\
\hline $\begin{array}{l}\text { Pleurotus tuber-regium } \\
\text { (Fr.) Singer }\end{array}$ & King of oyster & Edible & Picked from the forest (wild) \\
\hline $\begin{array}{c}\text { Termitomyces robustus } \\
\text { (Beeli) R. Heim }\end{array}$ & $\begin{array}{c}\text { Termite } \\
\text { mushroom }\end{array}$ & Edible & Picked from the forest (wild) \\
\hline $\begin{array}{c}\text { Lentinus squarrosulus } \\
\text { Mont. strain SQW }\end{array}$ & Unknown & Edible & $\begin{array}{l}\text { Cultivated on mixed sawdust of Triplochiton } \\
\text { scleroxylon and Chlorophora excelsa }\end{array}$ \\
\hline $\begin{array}{c}\text { Lentinus squarrosulus } \\
\text { Mont. strain LSF } \\
\end{array}$ & Unknown & Edible & $\begin{array}{l}\text { Cultivated on mixed sawdust of Triplochiton } \\
\text { scleroxylon and Chlorophora excelsa }\end{array}$ \\
\hline $\begin{array}{l}\text { Pleurotus sajor-caju }(\mathrm{Fr} .) \\
\text { Singer strain PScW }\end{array}$ & $\begin{array}{l}\text { Grey oyster } \\
\text { mushroom }\end{array}$ & Edible & $\begin{array}{l}\text { Cultivated on mixed sawdust of Triplochiton } \\
\text { scleroxylon and Chlorophora excelsa }\end{array}$ \\
\hline $\begin{array}{l}\text { Pleurotus ostreatus (Jacq.) } \\
\text { P. Kumm strain EM-1 }\end{array}$ & $\begin{array}{c}\text { Oyster } \\
\text { mushroom }\end{array}$ & Edible & $\begin{array}{l}\text { Cultivated on mixed sawdust of Triplochiton } \\
\text { scleroxylon and Chlorophora excelsa }\end{array}$ \\
\hline $\begin{array}{l}\text { Auricularia auricula }(\mathrm{L} .) \\
\text { Underw } \\
\end{array}$ & $\begin{array}{l}\text { Wood ear } \\
\text { mushroom }\end{array}$ & Edible & $\begin{array}{l}\text { Cultivated on mixed sawdust of Triplochiton } \\
\text { scleroxylon and Chlorophora excelsa }\end{array}$ \\
\hline
\end{tabular}




\subsection{Standards and Reagents}

Acetonitrile 99.9\% was of HPLC grade from Fisher Scientific (Lisbon, Portugal). The fatty acids methyl ester (FAME) reference standard mixture 37 (standard 47885-U) was purchased from Sigma (St. Louis, MO, USA), as were other individual fatty acid isomers, sugars (D(-)-fructose, D(-)-mannitol, $\mathrm{D}(+)$-raffinose pentahydrate, and $\mathrm{D}(+)$-trehalose), phenolic compounds (gallic, $p$-hydroxybenzoic, $p$-coumaric, protocatechuic and cinnamic acids) and Trolox (6-hydroxy-2,5,7,8-tetramethylchroman-2carboxylic acid). 2,2-Diphenyl-1-picrylhydrazyl (DPPH) was obtained from Alfa Aesar (Ward Hill, MA, USA). All other chemicals and solvents were of analytical grade and purchased from common sources. Water was treated in a Milli-Q water purification system (TGI Pure Water Systems, Greenville, SC, USA).

\subsection{Spawn and Substrate Preparation}

Tissue culture preparations of five cultivated mushroom species were inoculated onto Malt Extract Agar for mycelia growth of 7 days. Spawn was then prepared on sorghum grains in accordance to Oei [39]. The spawns were inoculated on sawdust of a mixture of Triplochiton scleroxylon and Chlorophora excelsa using the plastic bag method [40,41]. Fruit bodies of these mushrooms were harvested after the first flush, afterwards for each harvested mushroom sample, a mixture was performed and replicates were picked from these and previously sun dried samples, as stated above.

\subsection{Nutritional and Energetic Value}

The samples were analyzed for chemical composition (protein, fat, carbohydrates and ash) using the AOAC procedures [42]. The samples crude protein content $(\mathrm{N} \times 4.38)$ was estimated by the macro-Kjeldahl method; the crude fat was determined using a Soxhlet apparatus by extracting a known weight of sample with petroleum ether; the ash content was determined by incineration at $600 \pm 15^{\circ} \mathrm{C}$. Total carbohydrates were calculated by difference and total energy was calculated according to the following equations: Energy $(\mathrm{kcal})=4 \times(\mathrm{g}$ protein $+\mathrm{g}$ carbohydrates $)+9 \times(\mathrm{g}$ fat $)$.

\subsection{Lipophilic Compounds: Fatty Acids}

Fatty acids were determined after a transesterification procedure as described previously by the authors [2,43]. The fatty acids profile was analyzed with a DANI 1000 gas chromatographer (GC) equipped with a split/splitless injector and a flame ionization detector (FID). Fatty acid identification was made by comparing the relative retention times of FAME peaks from samples with standards. The results were recorded and processed using Clarity 4.0.1.7 Software (DataApex, Podohradska, Czech Republic) and expressed in relative percentage of each fatty acid.

\subsection{Hydrophilic Compounds}

Free Sugars. Sugars were determined by a high performance liquid chromatograph (HPLC) system consisted of an integrated system with a pump (Smartline system 1000, Knauer, Berlin, Germany), degasser system (Smart line manager 5000) and an auto-sampler (AS-2057 Jasco, Easton, MD, USA), coupled to a refraction index detector (RI detector Knauer Smartline 2300) as previously described by 
the authors $[2,43]$. Sugars identification was made by comparing the relative retention times of sample peaks with standards. Data were analyzed using Clarity 2.4 Software. Quantification was based on the RI signal response of each standard, using the internal standard (IS, raffinose) method and by using calibration curves obtained from the commercial standards of each compound. The results were expressed in g per $100 \mathrm{~g}$ of dry weight.

Organic acids. Organic acids were determined following a procedure previously described by the authors [23]. The analysis was performed using a Shimadzu 20A series UFLC (Shimadzu Coperation, Kyoto, Japan). Detection was carried out in a diode array detector (DAD), using $215 \mathrm{~nm}$ and $245 \mathrm{~nm}$ (for ascorbic acid) as preferred wavelengths. The organic acids found were quantified by comparison of the area of their peaks recorded at $215 \mathrm{~nm}$ with calibration curves obtained from commercial standards of each compound. The results were expressed in $\mathrm{g}$ per $100 \mathrm{~g}$ of dry weight.

Phenolic acids and related compound. Phenolic acids determination was performed using a Shimadzu 20A series ultra fast liquid chromatograph (UFLC, Shimadzu Cooperation, equipment described above) as previously described by Stojković et al. [43]. The phenolic compounds were characterised according to their UV, mass spectra and retention times compared with commercial standards when available. For the quantitative analysis of phenolic compounds, a calibration curve was obtained by injection of known concentrations $(5-80 \mu \mathrm{g} / \mathrm{mL})$ of different standard compounds. The results were expressed in mg per $100 \mathrm{~g}$ of dry weight.

\subsection{Minerals}

The whole mushrooms (pileus and stipe) were used for chemical analysis. All the minerals Copper $(\mathrm{Cu})$, Iron (Fe), Manganese (Mn), Magnesium (Mg), Lead (Pb), Zinc ( $\mathrm{Zn})$, Calcium (Ca) were analyzed by AAS (PerkinElmer AAnalyst 400, Waltham, MA, USA) spectrophotometer (Jenway 6300, Staffordshire, UK) after wet digestion of the samples [40]. The ascorbic acid method for color development was used in the determination of Phosphorus (P). A flame photometer (Jenway PFP 7, Staffordshire, UK) was used in the determination of Potassium (K) and Sodium (Na).

\subsection{Antioxidant Activity Evaluation}

Extract preparation. The lyophilized samples $(1 \mathrm{~g})$ were extracted twice by stirring with methanol $(40 \mathrm{~mL})$ for $1 \mathrm{~h}$ and subsequently filtered through Whatman No. 4 paper. The combined methanolic extracts were evaporated at $40{ }^{\circ} \mathrm{C}$ (rotary evaporator Büchi R-210, Büchi, Flawil, Switzerland) to dryness and re-dissolved in methanol $(20 \mathrm{mg} / \mathrm{mL})$. Successive dilutions were made from the stock solution and submitted to the following in vitro assays.

Antioxidant activity assays. Reducing power was evaluated by the reduction of the Folin-Ciocalteu reagent at $765 \mathrm{~nm}$ (Analytik Jena spectrophotometer; Jena, Germany), and by the capacity to convert $\mathrm{Fe}^{3+}$ into $\mathrm{Fe}^{2+}$ at $690 \mathrm{~nm}$ using a microplate reader (ELX800 Bio-Tek Instruments, Inc; Winooski, VT, USA). DPPH radical scavenging activity was evaluated in the microplate reader mentioned above, measured at $515 \mathrm{~nm}$. Inhibition of $\beta$-carotene bleaching was evaluated through the $\beta$-carotene/linoleate assay, measured at $470 \mathrm{~nm}$. Lipid peroxidation inhibition in porcine brain homogenates was evaluated by the decrease in thiobarbituric acid reactive substances (TBARS), measured at $532 \mathrm{~nm}$ [43]. The 
sample concentrations $(\mathrm{mg} / \mathrm{mL})$ providing $50 \%$ of antioxidant activity or 0.5 of absorbance (EC50) were calculated from the graphs of antioxidant activity percentages (DPPH, $\beta$-carotene/linoleate and TBARS assays) or absorbance at $690 \mathrm{~nm}$ (ferricyanide/Prussian blue assay) against sample concentrations. In the Folin-Ciocalteu assay the results were expressed as $\mathrm{mg}$ of gallic acid equivalents (GAE) per g of extract. Trolox was used as a positive control.

\subsection{Statistical Analysis}

Three samples were used and all the assays were carried out in triplicate. The results are expressed as mean values and standard deviation (SD). The results were analysed using one-way analysis of variance (ANOVA) followed by Tukey's HSD Test with $p=0.05$. This analysis was carried out using SPSS v. 22.0 program (IBM Corp., Armonk, NY, USA).

\section{Conclusions}

Oyster mushrooms (Pleurotus species) are the main cultivated mushrooms in Ghana, and studies on their cultivation using different agricultural wastes have been performed. Nevertheless, the knowledge about nutritional value, chemical composition in lipophilic and hydrophilic molecules, minerals and antioxidant properties of mushroom species from Ghana, are not yet well disseminated. This research concluded that either wild or cultivated samples are nutritionally rich in carbohydrates and proteins, presenting low levels of macro- and micro-elements, and low fat contents (making them excellent for inclusion in low caloric diets). With respect to their high antioxidant potential, mushrooms can find different applications, namely as functional foods or a source of nutraceuticals, maintaining and promoting health and life quality.

\section{Acknowledgments}

The authors are grateful to Foundation for Science and Technology (FCT, Portugal) for financial support to the research center CIMO (strategic project PEst-OE/AGR/UI0690/2011), A. Fernandes grant (SFRH/BD/76019/2011) and L. Barros researcher contract under "Programa Compromisso com Ciência-2008”. The authors also thank Africa-Brazil Agricultural Innovation Marketplace for funding the collection of the mushroom samples and the mineral analysis in Ghana.

\section{Author Contributions}

Conducted bibliographic research and data organization: Mary Obodai, Ângela Fernandes and Lillian Barros; Conducted the nutritional value, lipophilic and hydrophilic compounds analysis, and the antioxidant activity assays: Ângela Fernandes, Lillian Barros and Isabel C.F.R. Ferreira; Conducted the mineral determinations: Mary Obodai, Deborah L. Narh Mensah, Matilda Dzomeku, Juanita Prempeh and Richard K. Takli; Conducted the samples collection and preparation: Mary Obodai; Deborah L. Narh Mensah, Matilda Dzomeku, Arailde F. Urben, Juanita Prempeh and Richard K. Takli; Wrote or contributed to the writing of the manuscript: Mary Obodai, Isabel C.F.R. Ferreira, Ângela Fernandes, Lillian Barros; revised the manuscript writing: Isabel C.F.R Ferreira and Mary Obodai. 


\section{Conflicts of Interest}

The authors declare no conflict of interest.

\section{References}

1. Lee, S.S.; Chang, Y.S.; Noraswati, M.N.R. Utilization of macrofungi by some indigenous communities for food and medicine in Peninsular Malaysia. For. Ecol. Manag. 2009, 257, 2062-2065.

2. Grangeia, C.; Heleno, S.A.; Barros, L.; Martins, A.; Ferreira, I.C.F.R. Effects of trophism on nutritional and nutraceutical potential of wild edible mushrooms. Food Res. Int. 2011, 44, 1029-1035.

3. Obodai, M.; Apetorgbor, M. An Ethnobotanical Study of Mushroom Germplasm and Its Domestication in the Bia Biosphere Reserve; Report presented to UNESCO through Environmental Protection Agency of Ghana; Environmental Protection Agency of Ghana: Accra, Ghana, 2001.

4. Kirk, P.; Cannon, P.F.; Minter, D.W.; Stalpers, J.A. Ainsworth \& Bisby's Dictionary of the Fungi, 10th ed.; CAB International: Wallingford, UK, 2008.

5. Oboh, G.; Shodehinde, S.A. Distribution of nutrients, polyphenols and antioxidant activities in the pilei and stipes of some commonly consumed edible mushrooms in Nigeria. Bull. Chem. Soc. Ethiop. 2009, 23, 391-398.

6. Masamba, K.G.; Kazombo-Mwale, R. Determination and Comparaison of nutrient contents between cultivated and indigenously grown edible mushrooms. Afr. J. Food Sci. 2010, 4, 176-179.

7. Apetorgbor, M.M.; Apetorgbor, A.K.; Obodai, M. Indigenous knowledge and utilization of edible mushrooms in parts of Southern Ghana. Ghana J. For. 2006, 19, 20-34.

8. García-Lafuente, A.; Moro, C.; Villares, A.; Guillamón, E.; Rostagno, M.A.; D’Arrigo, M.; Martínez, J.A. Mushrooms as a source of anti-inflammatory agents. Am. J. Comm. Psychol. 2011, $48,125-141$.

9. Schillaci, D.; Arizza, V.; Gargano, M.L.; Venturella, G. Antibacterial activity of Mediterranean Oyster Mushrooms, Species of genus Pleurotus (Higher Basidiomycetes). Int. J. Med. Mushroom 2013, 15, 591-594.

10. Manzi, P.; Aguzzi, A.; Pizzoferrato, L. Nutritional value of mushrooms widely consumed in Italy. Food Chem. 2001, 73, 321-325.

11. Dzomeku, M. Studies on the Occurrence, Ethnomycology, and Cultivation of Pleurotus Tuber-Regium, M.Phil. Master's Thesis, Department of Theoretical and Applied Biology Kwame Nkrumah University of Science and Technology, Kumasi, Ghana, 2009.

12. Aletor, V.A. Compositional studies on edible tropical species of mushrooms. Food Chem. 1995, $54,265-268$.

13. Gbolagade, J.; Ajayi, A.; Oku, I.; Wankasi, D. Nutritive value of common wild edible mushrooms from Southern Nigeria. Glob. J. Biotechnol. Biochem. 2006, 1, 16-21.

14. Bonatti, M. Evaluation of Pleurotus ostreatus and Pleurotus sajor-caju nutritional characteristics when cultivated in different lignocellulosic wastes. Food Chem. 2004, 88, 425-428.

15. Manzi, P.; Gambelli, L.; Marconi, S.; Vivanti, V.; Pizzoferrato, L. Nutrients in edible mushrooms: An inter-species comparative study. Food Chem. 1999, 65, 477-482. 
16. Patil, S.S.; Ahmed, S.A.; Telang, S.M.; Baig, M.M.V. The nutritional value of Pleurotus ostreatus (jacq.:fr.) kumm cultivated on different lignocellulosic agrowastes. Innovat. Rom. Food Biotechnol. 2010, 7, 66-76.

17. Fan, L.; Soccol, C.R.; Pandey, A. Produção de cogumelo comestível Pleurotus em casca de café e avaliação do grau de detoxificação do substrato. In Proceedings of the Symposium Search of Coffee from Brazil, Poços de Caldas, Brazil, 26-29 September 2000; Volume 1, pp. 687-690.

18. Beluhan, S.; Ranogajec, A. Chemical composition and non-volatile components of Croatian wild edible mushrooms. Food Chem. 2011, 124, 1076-1082.

19. Dimou, D.M.; Georgala, A.; Komaitis, M.; Aggelis, G. Mycelial fatty acid composition of Pleurotus spp. and its application in the intrageneric differentiation. Mycol. Res. 2002, 106, 925-929.

20. Papaspyridi, L.-M.; Sinanoglou, V.J.; Strati, I.F.; Katapodis, P.; Christakopoulos, P. Fatty acid profile of Pleurotus ostreatus and Ganoderma australe grown naturally and in a batch bioreactor. Acta Aliment. 2013, 42, 328-337.

21. Reis, F.S.; Barros, L.; Martins, A.; Ferreira, I.C.F.R. Chemical composition and nutritional value of the most widely appreciated cultivated mushrooms: An inter-species comparative study. Food Chem. Toxicol. 2012, 50, 191-197.

22. Gupta, A.; Sharma, S.; Saha, S.; Walia, S. Yield and nutritional content of Pleurotus sajor caju on wheat straw supplemented with raw and detoxified mahua cake. Food Chem. 2013, 141, 4231-4239.

23. Barros, L.; Pereira, C.; Ferreira, I.C.F.R. Optimized analysis of organic acids in edible mushrooms from Portugal by Ultra Fast Liquid Chromatography and Photodiode Array Detection. Food Anal. Methods 2013, 6, 309-316.

24. Reis, F.S.; Martins, A.; Barros, L.; Ferreira, I.C.F.R. Antioxidant properties and phenolic profile of the most widely appreciated cultivated mushrooms: A comparative study between in vivo and in vitro samples. Food Chem. Toxicol. 2012, 50, 1201-1207.

25. Silvestre, M.D.; Lagarda, M.J.; Farra, R.; Martineze-Costa, C.; Brines, J. Copper, iron and zinc determination in human milk using FAAS with microwave digestion. Food Chem. 2000, 68, 95-99.

26. WHO. World Health Organization Evaluation of Certain Foods Additives and Contaminants (Twenty-Six Report of the Joint FAO/WHO Expert Committee on Food Additives); WHO Technical Report Series, No. 683; WHO Library Cataloguing-in-Publication Data; WHO: Geneva, Switzerland, 1982.

27. Tüzen, M.; Özdemir, M.; Demirbas, A. Study of heavy metals in some cultivated and uncultivated mushrooms of Turkish origin. Food Chem. 1998, 63, 247-251.

28. Soylak, M.; Saracoglu, S.; Tüzen, M.; Mendli, D. Determination of trace metals in mushroom samples from Kayseri, Turkey. Food Chem. 2005, 92, 649-652.

29. Tüzen, M. Determination of heavy metals in soil, mushroom and plant samples by atomic absorption spectrometry. MicroChem. J. 2003, 74, 289-297.

30. Sesli, E; Tüzen, M. Levels of trace elements in the fruiting bodies of macrofungi growing in the east Black sea region of Turkey. Food Chem. 1999, 65, 453-460.

31. Isıloğlu, M.; Yilmaz, F.; Merdivan, M. Concentrations of trace elements in wild edible mushrooms. Food Chem. 2001, 73, 169-175. 
32. Unak, P.; Lambrecht, F.Y.; Biber, F.Z.; Darcan, S. Iodine measurements by isotope dilution analysis in drinking water in Western Turkey. J. Radioanal. Nucl. Chem. 2007, 273, 649-651.

33. Vonugopal, B.; Luckey, T. Toxicity of Non-Radioactive Heavy Metals and Their Salts in Heavy Metals Toxicity, Safety and Hormology; Coulston, F., Ed.; Georg Thieme: Stuttgart, Germany; Academic Press: New York, NY, USA, 1975.

34. Svoboda, L.; Kalac, P. Contamination of two edible Agaricus spp. mushrooms growing in a town with cadium, lead and mercury. Bull. Environ. Contam. Toxicol. 2003, 71, 123-130.

35. Zhu, F.; Qu, L.; Fan, W.; Qiao, M.; Hao, H.; Wang, X. Assessment of heavy metals in some wild edible mushrooms collected from Yunnan Province, China. Environ. Monit. Assess. 2011, 179, 191-199.

36. Radulescu, C.; Stihi, C.; Popescu, I.V.; Busuioc, G.; Gheboianu, A.I.; Cimpoca, V.G.; Dulama, I.D.; Diaconescu M. Determination of heavy metals content in wild mushrooms and soil by EDXRF and FAAS techniques. Ovidus Uni. Ann. Chem. 2010, 21, 9-14.

37. Okoro, I.O. Antioxidant activities and phenolic contents of three mushroom species, Lentinus squarrosulus Mont., Volvariella esculenta (Massee) Singer and Pleurocybella porrigens (Pers.) Singer. Int. J. Nutr. Metab. 2012, 4, 72-76.

38. Ferreira, I.C.F.R.; Baptista, P.; Vilas-Boas, M.; Barros, L. Free-radical scavenging capacity and reducing power of wild edible mushrooms from northeast Portugal: Individual cap and stipe activity. Food Chem. 2007, 100, 1511-1516.

39. Oei, P. Manual on Mushroom Cultivation: Techniques, Species and Opportunities for Commercial Application in Developing Countries; CTA: Wageningen, The Netherlands, 1991.

40. Auetrugal, A. The highest aspects for cultivating oak mushroom (Lentinula edodes) in plastic bags. Mushroom Newsl. Trop. 1984, 5, 11-15.

41. Obodai, M.; Dzomeku, M.; Awotwe, B.; Takli, R.K.; Narh, D. Manual on Mushroom Cultivation Technology in Ghana; CSIR-FRI Technical Report; The Food Research Institute (FRI) of the Council for Scientific and Industrial Research (CSIR): Accra, Ghana, 2007.

42. AOAC. Official Methods of Analysis, 16th ed.; Association of Official Analytical Chemists: Arlington, TX, USA, 1995.

43. Stojković, D.; Reis, F.S.; Barros, L.; Glamočlija, J.; Ćirić, A.; van Griensven, L.J.; Soković, M.; Ferreira, I.C.F.R. Nutrients and non-nutrients composition and bioactivity of wild and cultivated Coprinus comatus (O.F.Müll.) Pers. Food Chem. Toxicol. 2013, 59, 289-296.

Sample Availability: Samples of the mushrooms are available from the authors.

(C) 2014 by the authors; licensee MDPI, Basel, Switzerland. This article is an open access article distributed under the terms and conditions of the Creative Commons Attribution license (http://creativecommons.org/licenses/by/4.0/). 